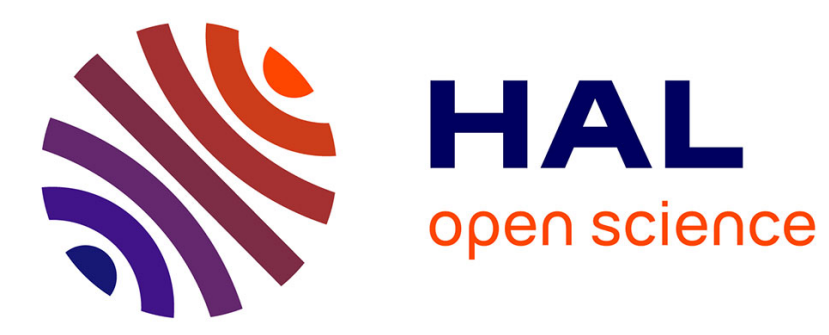

\title{
The last deglaciation in the southern ocean
}

Monique Labracherie, Laurent D Labeyrie, Josette Duprat, Edouard Bard, Maurice Arnold, Jean-Jacques Pichon, Jean-Claude Duplessy

\section{To cite this version:}

Monique Labracherie, Laurent D Labeyrie, Josette Duprat, Edouard Bard, Maurice Arnold, et al.. The last deglaciation in the southern ocean. Paleoceanography, 1989, 4 (6), pp.629-638. 10.1029/PA004i006p00629 . hal-03554965

\section{HAL Id: hal-03554965 https://hal.science/hal-03554965}

Submitted on 3 Feb 2022

HAL is a multi-disciplinary open access archive for the deposit and dissemination of scientific research documents, whether they are published or not. The documents may come from teaching and research institutions in France or abroad, or from public or private research centers.
L'archive ouverte pluridisciplinaire HAL, est destinée au dépôt et à la diffusion de documents scientifiques de niveau recherche, publiés ou non, émanant des établissements d'enseignement et de recherche français ou étrangers, des laboratoires publics ou privés. 
PALEOCEANOGRAPHY, VOL. 4, NO. 6, PAGES 629-638, DECEMBER 1989

\section{THE LAST DEGLACIATION IN THE SOUTHERN OCEAN}

Monique Labracherie, ${ }^{1}$ Laurent D. Labeyrie, ${ }^{2}$ Josette Duprat, ${ }^{1}$ Edouard Bard, ${ }^{2}$ Maurice Amold, ${ }^{2}$ Jean-Jacques Pichon, ${ }^{1}$ and Jean-Claude Duplessy 2

Abstract. The isotopic and micropaleontological deglacial records of three deep-sea cores from $44^{\circ} \mathrm{S}$ to $55^{\circ} \mathrm{S}$ have been dated by accelerator mass spectrometry. The available records did not allow accurate dating of the initiation of the deglaciation. By 13,000 years B.P., sea surface temperatures reached values similar to the present values. $A$ cool oscillation abruptly interrupted this warm phase between 12,000 and 11,000 years B.P. Initiation of this cooling therefore preceded the northern hemisphere Younger Dryas by approximately 1000 years. Complete warming was reached by 10,000 years B.P., more or less synchronous with the northeast Atlantic Ocean.

\section{INTRODUCTION}

The hydrological response of the surface ocean to the last glacial-Holocene transition has been recently the subject of numerous studies supported by detailed ${ }^{14} \mathrm{C}$ dating with accelerator mass spectrometry (AMS). Most are concentrated in the northern and eastern Atlantic ocean [Duplessy et al., 1986; 1989; Bard et al. , 1987; Broecker et al., 1988] with few in the Pacific [Duplessy et al., 1989; Kallel et al., 1988; Shackleton et al., 1988]. Biostratigraphical studies seem to indicate that the surface waters warmed earlier (by few

\footnotetext{
${ }^{1}$ Département de Géologie et Océanographie, Université de Bordeaux 1, Talence, France.

${ }^{2}$ Centre des Faibles Radioactivités, Laboratoire mixte CNRS-CEA, Gif sur Yvette, France.
}

\section{Copyright 1989}

by the American Geophysical Union. thousand years) in the southern ocean than in the northern Atlantic, both for the last and the penultimate glacialinterglacial transitions [Hays, 1978; Morley and Robinson, 1980; CLIMAP Project Members, 1984]. Yet quantitative informations on the timing of the southern hemisphere deglacial records are still insufficient to explore the reasons for this lead and understand the interhemispheric teleconnections of climate. In this paper we document the timing of the changes in surface water temperature and foraminiferal isotopic ratio during the last deglaciation between $44^{\circ} \mathrm{S}$ and $54^{\circ} \mathrm{S}$ by ${ }^{14} \mathrm{C}$ AMS dating of planktonic foraminifera in three cores located in the Indian sector of the southern ocean, between Crozet and Heard islands (MD 73-025 at $43^{\circ} 49$ 'S, $51^{\circ} 19^{\prime} \mathrm{E}$, $3284 \mathrm{~m}$; MD 84-527 at $43^{\circ} 49.3^{\prime} \mathrm{S}, 51^{\circ} 19.1^{\prime} \mathrm{E}, 3269 \mathrm{~m}$, and MD 84-551 at $55^{\circ} 00.5^{\prime} \mathrm{S}, 7^{\circ} 16.9^{\circ} \mathrm{E}, 2230 \mathrm{~m}$ ).

\section{THE SOUTHERN OCEAN PALEOCLIMATIC RECORDS}

Two types of climatic signals have been considered in this study: the oxygen isotope measurements $\left(\delta^{18} \mathrm{O}\right.$ versus PeeDee Belemnites Standard (PDB)) and the sea surface temperatures (SST) estimated from foraminiferal-based transfer function (T. F.):

The fractionation between calcium carbonate and water during foraminiferal growth depends strongly on the seawater temperature. The $\delta^{18} \mathrm{O}$ of foraminifera shells is therefore a function not only of the global variations in the isotopic composition of the oceans due to changes in the volume of ice stored over the continents, but also of the seawater temperature. In the case of the last deglaciation the total ice volume effect is thought to account for $\pm 1.1 \%$ [Labeyrie et al., 1987]. The local seawater $\delta^{18} \mathrm{O}$ depends also upon salinity variations and meltwater discharges in the proximity of the Antarctic ice sheet [Labeyrie et al., 1986]. The temperature contribution to the foraminiferal $\delta^{18} \mathrm{O}$ signal may not, therefore, be calculated directly. 
SST are estimated by multivariate statistical analysis of planktonic foraminifera [Imbrie and Kipp, 1971]. The transfer function (F1-3 T. F.) which relates faunal changes to SST has been adapted from the F I-2 T. F. of Hutson and Prell [1980]. The modern reference data set has been adjusted to optimize the coverage throughout the southern ocean and increase sensitivity to the low SST range. We used as reference data base the 33 subpolar and polar core tops from Hutson and Prell [1980] completed by 16 new Holocene core tops from the Polar Front zone and the Antarctic ocean. This new T. F. is based on the abundance variations of the 21 planktonic foraminifera species present in the sample selection.
A Q-mode factor analysis, applied on the matrix of core top assemblages following the procedures described by Imbrie and Kipp [1971], produces five distinct faunal associations, the varimax factors. The three first factors (Table 1) account for over $97 \%$ of the variance of the species distribution. The communalities are always larger than 0.96 . The varimax factor score matrix, which gives the statistical weight of the analyzed species for each of the first three factors, is given in Table 2.

We used a multicurvilinear regression by least-squares to relate the three major factors to modern SST; the reference winter and summer SST were obtained by interpolation from the 3-month average values given in the Southern Ocean Atlas data set [Gordon and Molinelli, 1986]. The water temperature

TABLE 1. Varimax Factor Matrix

\begin{tabular}{|c|c|c|c|c|c|c|c|c|c|}
\hline Core & Latitude & Longitude & $\begin{array}{c}\text { Depth } \\
\text { (m) }\end{array}$ & Com. & $\begin{array}{c}\text { Factor } \\
1\end{array}$ & $\begin{array}{c}\text { Factor } \\
2\end{array}$ & $\begin{array}{c}\text { Factor } \\
3\end{array}$ & $\begin{array}{c}\text { Factor } \\
4\end{array}$ & $\begin{array}{c}\text { Factor } \\
5\end{array}$ \\
\hline RC12-291* & $42^{\circ} 35^{\prime} S$ & $17^{\circ} 48^{\prime} \mathrm{W}$ & 3508 & 0.989 & 0.927 & -0.013 & 0.264 & 0.146 & 0.197 \\
\hline V22-106* & $46^{\circ} 08^{\prime} \mathrm{S}$ & $10^{\circ} 54^{\prime} \mathrm{W}$ & 3037 & 0.999 & 0.300 & -0.949 & 0.092 & -0.010 & 0.027 \\
\hline RC15-93* & $46^{\circ} 06^{\prime} \mathrm{S}$ & $13^{\circ} 14^{\prime} \mathrm{W}$ & 2714 & 0.998 & 0.516 & -0.799 & 0.175 & -0.011 & 0.249 \\
\hline $\mathrm{RC} 11-78^{*}$ & $50^{\circ} 52^{\prime} \mathrm{S}$ & $9^{\circ} 52^{\prime} \mathrm{W}$ & 3115 & 0.999 & 0.066 & -0.995 & 0.012 & 0.015 & -0.069 \\
\hline V22-107* & $44^{\circ} 28^{\prime} S$ & $6^{\circ} 38^{\prime} \mathrm{W}$ & 3998 & 0.997 & 0.974 & -0.194 & 0.096 & -0.037 & -0.011 \\
\hline V22-108* & $43^{\circ} 11^{\prime} S$ & $3^{\circ} 15^{\prime} \mathrm{W}$ & 4171 & 0.996 & 0.986 & -0.009 & 0.138 & -0.060 & -0.013 \\
\hline RC11-79* & $49^{\circ} 00^{\prime} S$ & $4^{\circ} 36^{\prime} \mathrm{W}$ & 3385 & 0.999 & 0.073 & -0.994 & 0.025 & 0.020 & -0.075 \\
\hline RC13-253* & $46^{\circ} 36^{\prime} \mathrm{S}$ & $7^{\circ} 38^{\prime} \mathrm{E}$ & 2494 & 1.000 & 0.639 & -0.762 & 0.049 & 0.017 & 0.088 \\
\hline RC13-275* & $50^{\circ} 43^{\prime} \mathrm{S}$ & $13^{\circ} 26^{\prime} \mathrm{E}$ & 1984 & 1.000 & 0.072 & -0.996 & 0.012 & 0.012 & -0.052 \\
\hline RC8-39* & $42^{\circ} 53^{\prime} \mathrm{S}$ & $42^{\circ} 21^{\prime} \mathrm{E}$ & 4330 & 0.992 & 0.910 & 0.015 & 0.289 & 0.276 & 0.055 \\
\hline RC8-40* & $43^{\circ} 47^{\prime S}$ & $46^{\circ} 12^{\prime} \mathrm{E}$ & 2540 & 0.990 & 0.799 & -0.314 & 0.347 & 0.363 & -0.019 \\
\hline V16-65* & $45^{\circ} 00^{\prime} \mathrm{S}$ & $45^{\circ} 46^{\mathrm{E}}$ & 1618 & 0.979 & 0.807 & -0.506 & 0.235 & 0.127 & -0.016 \\
\hline V16-64* & $46^{\circ} 01^{\prime} S$ & $44^{\circ} 22^{\prime} \mathrm{E}$ & 2202 & 0.976 & 0.821 & -0.524 & 0.142 & 0.088 & -0.012 \\
\hline RC8-41* & $43^{\circ} 38^{\prime} \mathrm{S}$ & $51^{\circ} 16^{\prime} \mathrm{E}$ & 2897 & 0.995 & 0.678 & -0.691 & 0.184 & -0.129 & -0.091 \\
\hline AR3-25* & $39^{\circ} 44^{\prime} \mathrm{S}$ & $67^{\circ} 53^{\prime} \mathrm{E}$ & 4065 & 0.963 & 0.458 & -0.003 & 0.867 & -0.033 & -0.037 \\
\hline AR4-63* & $39^{\circ} 50^{\prime S}$ & $75^{\circ} 03^{\prime} \mathrm{E}$ & 3768 & 0.943 & 0.371 & -0.040 & 0.893 & -0.081 & -0.014 \\
\hline RC11-122* & $38^{\circ} 02^{\prime S}$ & $83^{\circ} 29^{\prime} \mathrm{E}$ & 3490 & 0.953 & 0.433 & 0.031 & 0.850 & 0.196 & 0.052 \\
\hline RC11-121* & $39^{\circ} 43^{\prime} \mathrm{S}$ & $82^{\circ} 15^{\prime} \mathrm{E}$ & 3426 & 0.929 & 0.322 & 0.022 & 0.906 & -0.055 & 0.014 \\
\hline RC8-50* & $44^{\circ} 46^{\prime} \mathrm{S}$ & $92^{\circ} 25^{\circ} \mathrm{E}$ & 3219 & 0.998 & 0.872 & -0.084 & 0.397 & 0.269 & 0.028 \\
\hline E49-22* & $45^{\circ} 01^{\prime} \mathrm{S}$ & $95^{\circ} 04^{\prime} \mathrm{E}$ & 2717 & 0.984 & 0.833 & -0.240 & 0.432 & 0.214 & 0.014 \\
\hline E49-23* & $47^{\circ} 07^{\prime} \mathrm{S}$ & $95^{\circ} 04^{\prime} \mathrm{E}$ & 3207 & 0.997 & 0.916 & -0.362 & 0.150 & 0.061 & 0.006 \\
\hline E49-25* & $49^{\circ} 22^{\prime} \mathrm{S}$ & $94^{\circ} 49 \mathrm{E}$ & 3335 & 0.998 & 0.887 & -0.429 & 0.152 & 0.010 & -0.071 \\
\hline E49-24* & $47^{\circ} 59^{\prime} \mathrm{S}$ & $95^{\circ} 02^{\prime} \mathrm{E}$ & 3164 & 0.987 & 0.873 & -0.442 & 0.104 & 0.136 & -0.003 \\
\hline RC9-143* & $41^{\circ} 22^{\prime} S$ & $114^{\circ} 08^{\prime} \mathrm{E}$ & 4396 & 0.998 & 0.943 & 0.054 & 0.246 & -0.207 & -0.038 \\
\hline E45-81* & $43^{\circ} 58^{\prime} \mathrm{S}$ & $114^{\circ} 21^{\prime} \mathrm{E}$ & 4158 & 0.995 & 0.917 & -0.031 & 0.295 & -0.252 & -0.039 \\
\hline $\mathrm{E} 45-77^{*}$ & $46^{\circ} 27^{\prime} S$ & $114^{\circ} 25^{\prime} \mathrm{E}$ & 3740 & 0.995 & 0.983 & -0.131 & 0.086 & -0.047 & -0.047 \\
\hline E45-73* & $47^{\circ} 33 ' S$ & $114^{\circ} 26^{\prime} \mathrm{E}$ & 3690 & 1.000 & 0.954 & -0.295 & 0.042 & 0.015 & -0.021 \\
\hline E45-70* & $48^{\circ} 30^{\prime} \mathrm{S}$ & $114^{\circ} 28 \mathrm{E}$ & 3639 & 0.999 & 0.968 & -0.244 & 0.055 & 0.006 & -0.018 \\
\hline E44-27* & $53^{\circ} 02^{\prime} S$ & $119^{\circ} 43^{\prime} \mathrm{E}$ & 3508 & 1.000 & 0.509 & -0.856 & 0.047 & -0.017 & -0.078 \\
\hline RC9-140* & $45^{\circ} 25^{\prime} \mathrm{S}$ & $121^{\circ} 07^{\prime} \mathrm{E}$ & 4400 & 0.993 & 0.996 & -0.021 & 0.021 & -0.003 & -0.023 \\
\hline RC9-139* & $47^{\circ} 46 ' S$ & $123^{\circ} 06^{\prime} \mathrm{E}$ & 4158 & 0.997 & 0.995 & -0.038 & 0.059 & -0.028 & -0.043 \\
\hline RC8-61* & $46^{\circ} 32 ' S$ & $125^{\circ} 34^{\prime} \mathrm{E}$ & 4254 & 0.994 & 0.964 & -0.106 & 0.181 & -0.143 & -0.020 \\
\hline RC8-62* & $49^{\circ} 20^{\prime} \mathrm{S}$ & 127'07'E & 3875 & 0.98 & 0.975 & -0.110 & 0.097 & 0.022 & 0.078 \\
\hline MD84-548 & 7'S & $74^{\circ} 42 \mathrm{E}$ & 2390 & 1.000 & 0.061 & -0.996 & 0.004 & 0.004 & -0.064 \\
\hline MD84-552 & $54^{\circ} 55^{\prime S}$ & $73^{\circ} 50^{\prime} \mathrm{E}$ & 1780 & 1.000 & 0.079 & -0.996 & 0.012 & 0.008 & -0.031 \\
\hline MD84-528 & $46^{\circ} 10^{\prime} \mathrm{S}$ & $53^{\circ} 04^{\prime} \mathrm{E}$ & 3408 & 0.998 & 0.737 & -0.64 & -0.021 & 0.105 & 0.161 \\
\hline MD84-551 & $55^{\circ} 00^{\prime} \mathrm{S}$ & $73^{\circ} 17^{\prime} \mathrm{E}$ & 2230 & 1.000 & 0.129 & -0.983 & 0.005 & 0.012 & 0.132 \\
\hline MD84-550 & $56^{\circ} 46^{\prime} \mathrm{S}$ & $71^{\circ} 23 \mathrm{E}$ & 4080 & 1.000 & 0.061 & -0.995 & 0.004 & 0.005 & -0.074 \\
\hline MD84-557 & $53^{\circ} 20^{\prime} \mathrm{S}$ & $75^{\circ} 48 \mathrm{E}$ & 1084 & 1.000 & 0.065 & -0.996 & 0.003 & 0.005 & -0.064 \\
\hline MD84-553 & $54^{\circ} 41^{\prime} \mathrm{S}$ & $76^{\circ} 33 \mathrm{E}$ & 1504 & 1.000 & 0.076 & -0.997 & 0.001 & 0.005 & -0.025 \\
\hline MD84-562 & $51^{\circ} 55^{\prime} \mathrm{S}$ & $68^{\circ} 14 \mathrm{E}$ & 3553 & 1.000 & 0.221 & -0.975 & -0.008 & 0.035 & 0.002 \\
\hline MD84-563 & $50^{\circ} 43^{\prime} \mathrm{S}$ & $68^{\circ} 09 \mathrm{E}$ & 1720 & 1.000 & 0.104 & -0.985 & 0.007 & 0.012 & 0.137 \\
\hline MD84-560 & $53^{\circ} 07^{\prime} S$ & $72^{\circ} 10^{\prime} \mathrm{E}$ & 950 & 1.000 & 0.107 & -0.991 & 0.000 & 0.011 & -0.073 \\
\hline MD84-568 & $48^{\circ} 36^{\prime} \mathrm{S}$ & $72^{\circ} 40^{\prime} \mathrm{E}$ & 2241 & 1.000 & 0.093 & -0.944 & 0.010 & -0.002 & 0.317 \\
\hline MD80-304 & $51^{\circ} 00^{\prime} \mathrm{S}$ & $67^{\circ} 00 \mathrm{E}$ & 1950 & 1.000 & 0.058 & -0.993 & 0.056 & 0.056 & -0.061 \\
\hline MD24-K63 & $51^{\circ} 56 \mathrm{~S}$ & $42^{\circ} 53^{\prime} \mathrm{E}$ & 2550 & 1.000 & 0.069 & -0.997 & 0.005 & 0.006 & -0.019 \\
\hline
\end{tabular}


TABLE 1 (continued)

\begin{tabular}{|c|c|c|c|c|c|c|c|c|c|}
\hline$\overline{\text { Core }}$ & Latitude & Longitude & $\begin{array}{l}\text { Depth } \\
\text { (m) }\end{array}$ & Com. & $\begin{array}{c}\text { Factor } \\
1\end{array}$ & $\begin{array}{c}\text { Factor } \\
2 \\
\end{array}$ & $\begin{array}{c}\text { Factor } \\
3 \\
\end{array}$ & $\begin{array}{c}\text { Factor } \\
4 \\
\end{array}$ & $\begin{array}{c}\text { Factor } \\
5 \\
\end{array}$ \\
\hline & & & 2. & & 0 & -0 & 0. & 5 & -0.0 \\
\hline & & 19 & 36 & 1. & 0.0 & & 0. & 5 & -0 . \\
\hline MD73-026 & $44^{\circ} 59^{\prime} \mathrm{S}$ & $53^{\circ} 17^{\prime} \mathrm{E}$ & 3429 & 1.000 & 0.304 & -0.903 & -0.004 & 0.055 & 0.298 \\
\hline Variance & & & & & 42.297 & 46.216 & 8.489 & 1.259 & 0.927 \\
\hline
\end{tabular}

List and location of the core tops utilized to establish the transfert function, and results of the Varimax analysis: Communality (Com.) and statistical weight of the five first factors for each of the stations. The samples from Hutson and Prell [1980] are marked by asterisks.

TABLE 2. Varimax Score Matrix

\begin{tabular}{lrrr}
\hline Species & Factor 1 & Factor 2 & Factor 3 \\
\hline G. pachyderma (left) & 0.061 & -0.995 & 0.004 \\
G. pachyderma (right) & -0.036 & 0.004 & 0.664 \\
G. bulloides & 0.955 & 0.061 & -0.187 \\
G. quinqueloba & 0.039 & -0.073 & 0.011 \\
G. scitula & -0.001 & 0.000 & 0.023 \\
G. glutinata & 0.071 & -0.004 & 0.176 \\
G. inflata & 0.266 & 0.016 & 0.674 \\
G. hirsuta & -0.004 & 0.000 & 0.031 \\
G. truncatulinoides (left) & 0.076 & 0.018 & 0.148 \\
G. truncatulinoides (right) & -0.005 & -0.001 & 0.059 \\
G. aequilateralis & -0.005 & 0.000 & 0.029 \\
G. falconensis & 0.006 & 0.002 & 0.002 \\
\hline
\end{tabular}

range is $-0.2^{\circ} \mathrm{C}$ to $15.5^{\circ} \mathrm{C}$ during summer and $-2.2^{\circ} \mathrm{C}$ to $13^{\circ} \mathrm{C}$ during winter. Correlation coefficients are 0.983 for summer and 0.978 for winter. The standard error is $\pm 1.27^{\circ} \mathrm{C}$ for summer and $\pm 1.38^{\circ} \mathrm{C}$ for winter within the selected temperature range. Yet as the foraminiferal population is monospecific (species Neogloboquadrina pachyderma s.) below a summer SST of $+3^{\circ} \mathrm{C}$, this temperature represents the lower limit for the foraminiferal T.F. The results of this T.F. applied to the foraminiferal specific distributions of core MD 73-025 and core MD 84-527 are reported in Table 3 and respectively in Figure $1 \mathrm{c}$ and $1 \mathrm{~g}$. The high communalities obtained during this calculation (always above 0.975 ) indicate that there is no distortion of the original information given by the modern reference. Core MD 84-551, located in the high southern

TABLE 3. Changes in the $\delta^{18} \mathrm{O}$ and Summer SST Measured on the Foraminifera From Cores MD 73-025, MD 84-527, and MD 84-551

\begin{tabular}{|c|c|c|c|c|c|c|c|c|c|c|c|c|}
\hline \multicolumn{5}{|c|}{ MD 73-025 } & \multicolumn{6}{|c|}{ MD 84-527 } & \multicolumn{2}{|c|}{ MD 84-551 } \\
\hline $\begin{array}{c}\text { depth } \\
\mathrm{cm}\end{array}$ & $\begin{array}{l}\text { age } \\
\text { kyr }\end{array}$ & $\begin{array}{r}\text { N. p. } \\
\delta 18\end{array}$ & $\begin{array}{l}\text { Non. } \\
818 *\end{array}$ & $\begin{array}{c}\text { SST } \\
{ }^{\circ} \mathrm{C}\end{array}$ & $\begin{array}{l}\text { depth } \\
\mathrm{cm}\end{array}$ & $\begin{array}{l}\text { age } \\
\text { kyr }\end{array}$ & $\begin{array}{l}\text { N. p. } \\
\delta 18\end{array}$ & $\begin{array}{l}\text { C. } w \\
\delta 18^{*}\end{array}$ & $\begin{array}{l}\text { G. b } \\
\delta 18\end{array}$ & $\begin{array}{l}\text { SST } \\
{ }^{\circ} \mathrm{C}\end{array}$ & $\begin{array}{l}\text { depth } \\
\mathrm{cm}\end{array}$ & $\begin{array}{l}\text { N. p. } \\
\delta 18\end{array}$ \\
\hline 0 & 02.40 & 2.40 & 3.61 & - & 0 & 01.75 & 1.98 & - & - & - & 0 & 3.15 \\
\hline 4 & 02.74 & 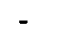 & 3.64 & - & 2 & 01.83 & - & - & 2.41 & - & 10 & 3.31 \\
\hline 10 & 03.25 & 1.95 & - & - & 5 & 01.95 & - & 3.73 & - & - & 20 & 3.00 \\
\hline 20 & 04.10 & 2.13 & - & - & 10 & 02.14 & 2.14 & - & 2.43 & 6.5 & 30 & 3.15 \\
\hline 24 & 04.28 & 0 & 3.35 & - & 13 & 02.26 & - & 3.69 & 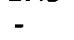 & - & 40 & 3.14 \\
\hline 30 & 04.55 & 2.39 & 3.30 & - & 20 & 02.53 & 2.14 & - & 2.5 & 6.8 & 50 & 3.27 \\
\hline 40 & 04.99 & 2.28 & 3.55 & - & 23 & 02.65 & - & $3.67-$ & & - & 60 & 3.13 \\
\hline 50 & 05.44 & 2.14 & 3.50 & - & 30 & 02.93 & 1.96 & 3.48 & 2.74 & 6.8 & 70 & 3.21 \\
\hline 60 & 05.88 & 1.66 & 3.54 & - & 40 & 03.32 & 1.71 & 3.17 & 2.62 & 5.9 & 80 & 3.09 \\
\hline 70 & 06.33 & 1.77 & 3.62 & - & 50 & 03.71 & 1.89 & 3.52 & 2.49 & 7.4 & 90 & 3.40 \\
\hline 80 & 06.78 & 2.07 & 3.57 & - & 53 & 03.83 & - & 3.81 & - & - & 100 & 3.20 \\
\hline 90 & 07.15 & 2.11 & - & - & 60 & 04.10 & 2.09 & 3.48 & - & 7.4 & 110 & 3.18 \\
\hline 100 & 07.46 & 1.91 & 3.76 & - & 62 & 04.16 & - & 2.42 & - & & 112 & 3.49 \\
\hline 110 & 07.77 & 2.06 & 3.80 & - & 70 & 04.42 & 2.15 & 3.79 & 2.56 & 6.8 & 122 & 3.85 \\
\hline 120 & 08.08 & 2.23 & 3.73 & - & 73 & 04.52 & - & 3.63 & - & - & 130 & 3.84 \\
\hline 130 & 08.38 & 1.88 & 3.76 & - & 75 & 04.58 & - & - & - & 7.3 & 140 & 3.04 \\
\hline 142 & 08.69 & 2.13 & 3.83 & - & 80 & 04.74 & 2.19 & 3.48 & 2.63 & $<$ - & 142 & 3.53 \\
\hline 150 & 09.00 & 1.95 & - & - & 83 & 04.84 & - & 3.59 & - & - & 150 & 4.08 \\
\hline 160 & 09.16 & 1.96 & 3.96 & - & 90 & 05.07 & 2.23 & 3.53 & 2.43 & - & 155 & 4.74 \\
\hline 170 & 09.31 & 1.83 & - & - & 100 & 05.39 & 2.01 & 3.66 & - & - & 160 & 4.78 \\
\hline 180 & 09.47 & 1.92 & 4.03 & - & 102 & 05.45 & - & - & 2.74 & - & 162 & 4.45 \\
\hline 190 & 09.62 & 2.01 & - & - & 110 & 05.71 & 1.90 & 3.37 & 2.52 & 6.8 & 172 & 4.10 \\
\hline 200 & 09.83 & 2.24 & 3.89 & - & 113 & 05.81 & - & 3.83 & - & - & 182 & 4.25 \\
\hline 210 & 10.10 & 2.28 & 4.14 & - & 120 & 06.03 & 2.14 & - & 2.32 & 6.1 & 192 & 4.29 \\
\hline
\end{tabular}


TABLE 3. (continued)

\begin{tabular}{|c|c|c|c|c|c|c|c|c|c|c|c|c|}
\hline \multicolumn{5}{|c|}{ MD 73-025 } & \multicolumn{6}{|c|}{ MD 84-527 } & \multicolumn{2}{|c|}{ MD 84-551 } \\
\hline $\begin{array}{c}\text { depth } \\
\mathrm{cm}\end{array}$ & $\begin{array}{l}\text { age } \\
\text { kyr }\end{array}$ & $\begin{array}{l}\text { N. p. } \\
\delta 18 \\
\end{array}$ & $\begin{array}{l}\text { Non. } \\
\delta 18 * \\
\end{array}$ & $\begin{array}{l}\text { SST } \\
{ }^{\circ} \mathrm{C}\end{array}$ & $\begin{array}{l}\text { depth } \\
\mathrm{cm}\end{array}$ & $\begin{array}{l}\text { age } \\
\text { kyr }\end{array}$ & $\begin{array}{l}\text { N. p. } \\
\delta 18 \\
\end{array}$ & $\begin{array}{l}\text { C. w } \\
\delta 18^{*} \\
\end{array}$ & $\begin{array}{l}\text { G. b } \\
\delta 18 \\
\end{array}$ & $\begin{array}{l}\text { SST } \\
\mathrm{C} \\
\end{array}$ & $\begin{array}{l}\text { depth } \\
\mathrm{cm}\end{array}$ & $\begin{array}{l}\text { N. p. } \\
\delta 18 \\
\end{array}$ \\
\hline $\begin{array}{l}212 \\
220 \\
222 \\
230 \\
232 \\
240 \\
242 \\
250 \\
252 \\
260 \\
262 \\
270 \\
272 \\
280 \\
282 \\
290 \\
292 \\
300 \\
310 \\
320 \\
330 \\
340 \\
350\end{array}$ & $\begin{array}{l}10.15 \\
10.36 \\
10.41 \\
10.70 \\
10.82 \\
11.30 \\
11.42 \\
12.00 \\
12.01 \\
12.04 \\
12.04 \\
12.07 \\
12.08 \\
12.60 \\
12.87 \\
14.71 \\
15.20 \\
17.16 \\
19.61 \\
22.06 \\
24.51 \\
28.30 \\
28.55\end{array}$ & $\begin{array}{l}- \\
2.33 \\
- \\
2.38 \\
- \\
2.94 \\
- \\
2.85 \\
- \\
3.20 \\
- \\
3.06 \\
- \\
2.67 \\
- \\
4.00 \\
- \\
4.01 \\
4.86 \\
4.13 \\
4.05 \\
4.34 \\
3.43\end{array}$ & $\begin{array}{l}- \\
4.30 \\
- \\
4.32 \\
- \\
4.38 \\
- \\
4.40 \\
- \\
4.42 \\
- \\
4.77 \\
- \\
5.12 \\
- \\
5.10 \\
- \\
5.20 \\
5.13 \\
- \\
4.97 \\
4.79 \\
4.95\end{array}$ & $\begin{array}{c}12.4 \\
- \\
11.1 \\
- \\
11 \\
- \\
4.5 \\
- \\
4.6 \\
- \\
4.8 \\
- \\
6.8 \\
- \\
7.1 \\
- \\
4.4 \\
4.5 \\
2.8 \\
4 \\
6 \\
2.2 \\
3.5\end{array}$ & $\begin{array}{l}130 \\
138 \\
140 \\
143 \\
150 \\
160 \\
170 \\
180 \\
190 \\
200 \\
210 \\
215 \\
220 \\
225 \\
230 \\
240 \\
250 \\
260 \\
270 \\
280 \\
290 \\
293 \\
300 \\
302 \\
310 \\
313 \\
320 \\
330 \\
340 \\
342 \\
350\end{array}$ & $\begin{array}{l}06.36 \\
06.61 \\
06.68 \\
06.77 \\
07.00 \\
07.39 \\
07.78 \\
08.18 \\
08.57 \\
08.96 \\
09.26 \\
09.41 \\
09.55 \\
09.70 \\
09.85 \\
10.16 \\
10.46 \\
10.98 \\
11.54 \\
12.10 \\
12.76 \\
12.84 \\
13.00 \\
14.20 \\
19.00 \\
20.80 \\
25.00 \\
25.80 \\
26.60 \\
26.76 \\
27.19\end{array}$ & $\begin{array}{l}1.80 \\
- \\
2.02 \\
- \\
2.26 \\
1.89 \\
2.36 \\
2.14 \\
1.98 \\
2.07 \\
1.64 \\
- \\
1.85 \\
- \\
1.63 \\
1.69 \\
2.32 \\
2.06 \\
2.22 \\
2.41 \\
2.29 \\
- \\
3.54 \\
3.68 \\
3.48 \\
3.43 \\
2.78 \\
3.39 \\
3.31\end{array}$ & $\begin{array}{l}3.29 \\
3.77 \\
- \\
3.67 \\
3.73 \\
3.85 \\
3.94 \\
3.90 \\
- \\
- \\
4.06 \\
- \\
4.20 \\
- \\
4.38 \\
4.43 \\
4.54 \\
4.60 \\
4.61 \\
5.13 \\
5.18 \\
5.04 \\
4.92 \\
5.26 \\
4.98 \\
5.02 \\
4.93 \\
4.95 \\
4.97 \\
- \\
4.94\end{array}$ & $\begin{array}{l}2.31 \\
- \\
2.28 \\
- \\
2.37 \\
- \\
2.39 \\
2.79 \\
2.37 \\
2.38 \\
2.60 \\
- \\
2.31 \\
- \\
2.68 \\
2.82 \\
2.74 \\
2.65 \\
- \\
3.54 \\
3.01 \\
- \\
3.03 \\
- \\
3.46 \\
- \\
3.31 \\
2.79 \\
- \\
3.45- \\
-\end{array}$ & $\begin{array}{l}4.9 \\
4.3 \\
- \\
6 \\
5.4 \\
4.1 \\
7 \\
8.3 \\
8.2 \\
- \\
8.5 \\
- \\
9.3 \\
7.9 \\
7.6 \\
6.8 \\
5.9 \\
3.3 \\
5.3 \\
6.4 \\
- \\
1.8 \\
- \\
2.2 \\
- \\
2.5 \\
2.8 \\
3.3 \\
2.6\end{array}$ & $\begin{array}{l}200 \\
202 \\
210 \\
220 \\
230 \\
240 \\
250 \\
260 \\
270 \\
280 \\
290 \\
300 \\
310 \\
316 \\
320 \\
326 \\
340 \\
346 \\
350\end{array}$ & $\begin{array}{l}4.11 \\
4.17 \\
4.06 \\
4.05 \\
3.82 \\
3.68 \\
4.00 \\
3.51 \\
3.78 \\
3.83 \\
3.86 \\
3.81 \\
3.55 \\
3.85 \\
3.48 \\
3.80 \\
3.83 \\
3.80 \\
3.67\end{array}$ \\
\hline
\end{tabular}

The isotopic analyses were done on a VG $602 \mathrm{C}$ mass spectrometer. The SST (summer sea surface temperatures) are estimated with the foraminiferal transfer function F 1.3 modified from Hutson and Prell [1980], as explained in the text. Analyses are reported versus depth : for core MD 73-025, ages, $\delta^{18} \mathrm{O}$ (versus PDB) of the planktonic species Neogloboquadrina pachyderma s., of the benthic species Melonis pompilioides (Nonion), and summer SST; for core MD 84-527, ages, $\delta^{18} \mathrm{O}$ of $N$. pachyderma s., $\delta^{18} \mathrm{O}$ of the benthic species Cibicides wuellerstorfi , $\delta^{18} \mathrm{O}$ of the planktonic species Globigerina bulloides (250- to 315- $\mu \mathrm{m}$ size fraction), and SST; for core MD 84-551, $\delta^{18} \mathrm{O}$ of $N$. pachyderma s.. Construction of the age scale is explained in the text.

$*$ Corrected for specific fractionation by $+0.4 \%$ o (M. pompilioides (Nonion)) or $+0.64 \%$ (G. bulloides)

latitude waters $\left(55^{\circ} \mathrm{S}\right)$ within the monospecific $N$. pachyderma $s$. assemblage zone, may not be studied by this transfer function.

The isotopic results are reported (as $\delta^{18} \mathrm{O} / \mathrm{PDB}$ ) versus depth in the cores in Table 3 and Figure 1. The oxygen isotopic ratios have been analyzed on the planktonic foraminifera polar species $N$. pachyderma $s$. in the three cores (Figures $1 b$, $1 \mathrm{f}$, and $1 \mathrm{j}$ ), and on the subpolar species Globigerina bulloides in core MD 84-527 (Figure 1e). The benthic foraminifera $\delta^{18} \mathrm{O}$ have been analyzed in core MD 73-025 (Melonis pompilioides, (Figure 1a)) and MD 84-527 (Cibicides wuellerstorfi, (Figure 1d)). Core MD 84-551 does not contain enough benthic foraminifera for the measurements.

\section{CHRONOLOGICAL FRAMEWORK AND SEDIMENTATION RATES}

The AMS ${ }^{14} \mathrm{C}$ dates were obtained from monospecific planktonic foraminifera samples (Figure 1 and Table 4). All dates are calculated with the 5.568 years half-life, and corrected for a constant surface water age of 480 years, the estimated prebomb age of surface waters at $45^{\circ} \mathrm{S}$ [Bard et al., 1989]. The equivalent estimated prebomb age of surface waters at the location of core MD 84-551 is 100 to 300 years older [Bard et al., 1989]; however, we have no idea how this age changed with time, so the same correction is taken for all the cores. For the same reason, an exact comparison with dates made on 


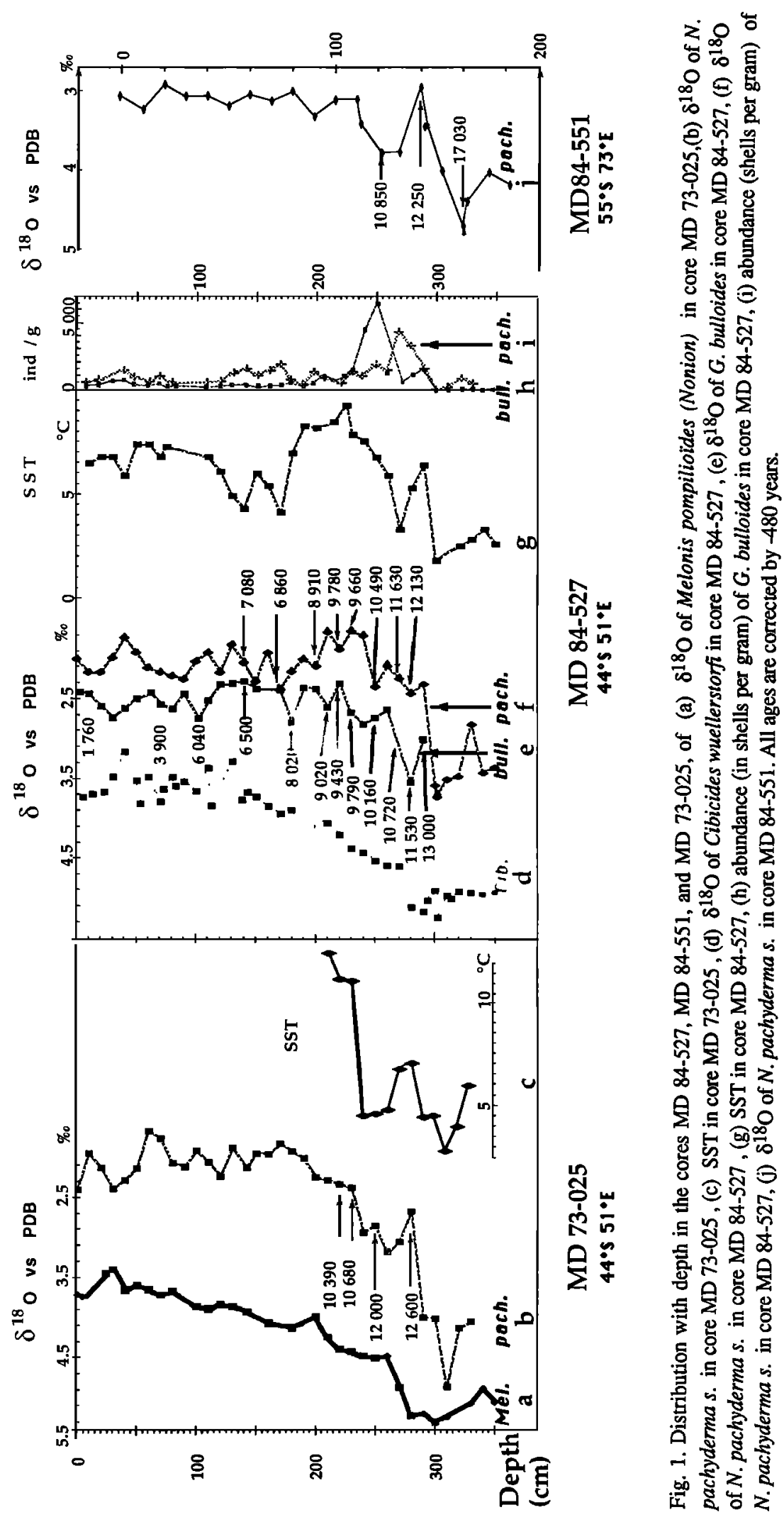


TABLE 4. AMS ${ }^{14} \mathrm{C}$ Ages for Cores $\mathrm{MD} 84-527, \mathrm{MD} 84-551$, and $\mathrm{MD}$ 73-025

\begin{tabular}{|c|c|c|c|c|c|}
\hline & depth & sp. & age $\mathrm{BP}$ & error $( \pm)$ & age -480 years \\
\hline $\begin{array}{l}\text { MD 84-551 } \\
\text { MD 73-025 }\end{array}$ & $\begin{array}{c}0-2 \\
60-62 \\
102-104 \\
142-144 \\
172-174 \\
200-202 \\
220-222 \\
230-232 \\
250-252 \\
270-272 \\
280-282 \\
290-292 \\
140-142 \\
170-174 \\
200-202 \\
220-222 \\
230-232 \\
250-252 \\
270-272 \\
280-282 \\
320-322 \\
342-344 \\
350-352 \\
360-364 \\
380-382 \\
400-402 \\
440-442 \\
120-122 \\
140-142 \\
160-162 \\
220-224 \\
230-234 \\
250-254 \\
280-284 \\
378-382 \\
388-392\end{array}$ & $\begin{array}{l}\text { bull. } \\
\text { bull. } \\
\text { bull. } \\
\text { bull. } \\
\text { bull. } \\
\text { bull. } \\
\text { bull. } \\
\text { bull. } \\
\text { bull. } \\
\text { bull. } \\
\text { bull. } \\
\text { bull. } \\
\text { pach. } \\
\text { pach. } \\
\text { pach. } \\
\text { pach. } \\
\text { pach. } \\
\text { pach. } \\
\text { pach. } \\
\text { pach. } \\
\text { pach. } \\
\text { pach. } \\
\text { pach. } \\
\text { pach. } \\
\text { pach. } \\
\text { pach. } \\
\text { pach. } \\
\text { pach. } \\
\text { pach. } \\
\text { pach. } \\
\text { bull. } \\
\text { bull. } \\
\text { pach. } \\
\text { bull. } \\
\text { pach. } \\
\text { pach. }\end{array}$ & $\begin{array}{c}2,240 \\
4,380 \\
6,520 \\
6,980 \\
8,500 \\
9,500 \\
9,910 \\
10,270 \\
10,640 \\
11,200 \\
12,010 \\
13,480 \\
7,560 \\
7,340 \\
9,390 \\
10,260 \\
10,140 \\
10,970 \\
12,110 \\
12,610 \\
25,450 \\
27,800 \\
28,470 \\
25,490 \\
28,830 \\
29,300 \\
31,260 \\
11,330 \\
12,720 \\
17,510 \\
10,870 \\
11,160 \\
12,480 \\
13,080 \\
39,050 \\
36,470\end{array}$ & $\begin{array}{c}90 \\
100 \\
100 \\
100 \\
130 \\
120 \\
120 \\
140 \\
120 \\
120 \\
140 \\
160 \\
130 \\
110 \\
110 \\
160 \\
120 \\
160 \\
140 \\
180 \\
480 \\
510 \\
570 \\
430 \\
550 \\
730 \\
730 \\
170 \\
200 \\
160 \\
140 \\
140 \\
160 \\
160 \\
1,800 \\
1300\end{array}$ & $\begin{array}{r}1,760 \\
3,900 \\
6,040 \\
6,500 \\
8,020 \\
9,020 \\
9,430 \\
9,790 \\
10,160 \\
10,720 \\
11,530 \\
13,000 \\
7,080 \\
6,860 \\
8,910 \\
9,780 \\
9,660 \\
10,490 \\
11,630 \\
12,130 \\
24,970 \\
27,320 \\
27,990 \\
25,010 \\
28,350 \\
28,820 \\
30,780 \\
10,850 \\
12,240 \\
17,030 \\
10,390 \\
10,680 \\
12,000 \\
12,600 \\
38,600 \\
36,000\end{array}$ \\
\hline
\end{tabular}

Approximately $5 \mathrm{mg}$ monospecific samples of foraminifera are prepared for each analysis, to allow for duplication. The species analyzed is either $G$. bulloides (bull) or $N$. pachyderma $s$. (pach). The correction of -480 years takes into account the present apparent ages of surface waters at $45^{\circ} \mathrm{S}$. The errors correspond to $1 \sigma$.

carbon from terrestrial plants would require more precise determination of the changes in ventilation of surface waters.

Two different species have been analyzed. N. pachyderma s. , the cold water species, was picked in the three cores; $G$. bulloides, the subpolar species, was picked only in core MD 84-527. The mean difference in the ages obtained for these two species at the same depths is not significant ( $170 \pm 230$ years).

A coherent picture of the changes in sedimentation rate with time at the location of neighbor cores MD 73-025 and MD 84527 is given by the AMS dates (Figure 2): the sedimentation rate has been constant, around $30 \mathrm{~cm} / \mathrm{kyr}$, between $13 \mathrm{kyr}$ B.P. and $2 \mathrm{kyr}$ B.P.. This rate insures that bioturbation mixing has a negligible effect on the measured ${ }^{14} \mathrm{C}$ dates during deglaciation. During the last glacial maximum, the sedimentation rate was much lower $(\approx 3 \mathrm{~cm} / \mathrm{kyr}$ for core $\mathrm{MD}$
84-527), and the records are not as reliable as during deglaciation. The only major difference in the age versus depth relationship occurs at the bottom of the analyzed records: Core MD 73-025 has a well- defined sedimentological unconformity at the base of a compact ash layer, at $370 \mathrm{~cm}$. An age of 38.6 kyr B.P. was obtained for this core at $380 \mathrm{~cm}$, whereas core MD 84-527 gives 28.4 kyr B.P. at the same depth, thus indicating that around $10 \mathrm{kyr}$ may have been lost from the MD 73-025 record. The more southem core MD 84-551 (55 $\left.{ }^{\circ} \mathrm{S}\right)$ has a lower sedimentation rate during deglaciation (approximately $13 \mathrm{~cm} / \mathrm{kyr}$ ). We have no absolute dates to constrain how sedimentation was reduced during the last glacial. Comparison of the foraminiferal $\delta^{18} \mathrm{O}$ records between cores MD 84-551 and MD 84-527 would give an approximate age of $25 \mathrm{kyr}$ B.P. at $170 \mathrm{~cm}$, which corresponds to a sedimentation rate around $1.5 \mathrm{~cm} / \mathrm{kyr}$ during the last glacial maximum. 


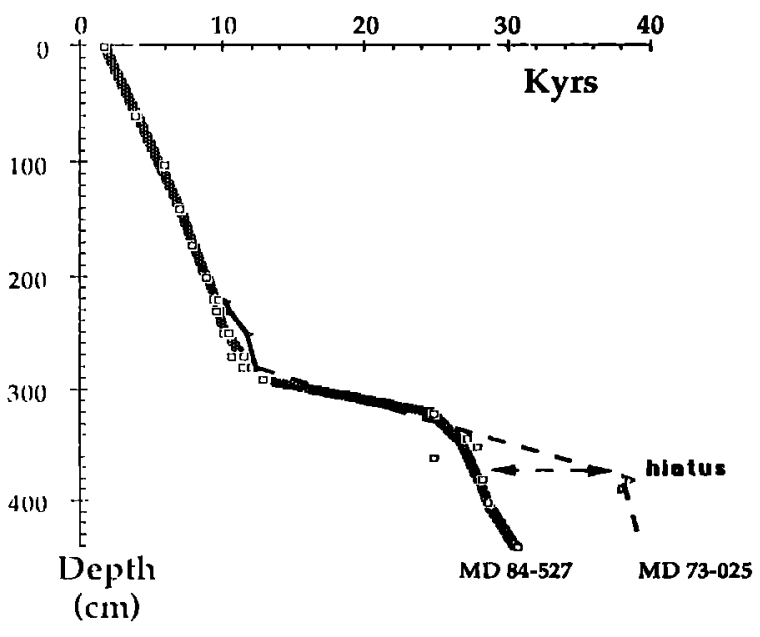

Fig. 2. Age-depth relations built using the AMS ${ }^{14} \mathrm{C}$ datings of $N$. pachyderma s. in core MD 73-025 and G. bulloides and $N$. pachyderma s. in core MD 84-527. All ages are corrected by -480 years.

A composite graph of the changes versus time of the foraminiferal $\delta^{18} \mathrm{O}$ and summer SST has been reconstructed, to help comparison between the records of cores MD 73-025 and MD 84-527 (Figure 3). The proposed age scale was built in several steps: An optimum correlation was established between the isotopic and SST signals of both cores, serving as reference with the available ${ }^{14} \mathrm{C}$ dates to build a common agedepth relationship (Table 5). The final age scale was estimated by linear interpolation between the representative levels (Table 3 ). This detailed correlation was complicated by small differences between the records, apparent by example around $250 \mathrm{~cm}$ in both cores for the $N$. pachyderma $\delta^{18} \mathrm{O}$ signal (Figures $1 \mathrm{~b}$ and $1 \mathrm{f}$ ) as well as the SST signals (Figures $1 \mathrm{c}$ and $1 \mathrm{~g}$ ). There is a larger difference around $300 \mathrm{~cm}, N$. pachyderma $\delta^{18} \mathrm{O}$ being significantly more positive in core MD 73-025 that in core MD 84-527. Apparently, the different records of core MD 84-527 were slightly perturbed during handling of the core barrel on the ship deck. A small amount of sediment was lost during section of the core liner at $300 \mathrm{~cm}$ : the sediment at these latitudes contains between 50 and $90 \%$ diatoms, and fluidifies by tixotropy during core retrieval operations (especially when the core barrel is deposited horizontally on the deck for extraction and section). The larger core diameter of core MD 84-527 (10 cm, compared to $7 \mathrm{~cm}$ for core MD 73025 ) facilitates differential settling of the heavier benthic foraminifera, and flowing along the core of the lighter planktonic foraminifera and diatoms, specially during the core section. As the number of foraminiferal shells per gram of sediment changes significantly along core MD 84-527 (Figures $1 \mathrm{~h}$ and 1i.), the resulting transfer of some of the foraminifera shells from the high abundance levels $(290 \mathrm{~cm}$ and above) to the low abundance levels $(300 \mathrm{~cm}$ and below) may explain the disappearance of the last glacial maximum $\delta^{18} \mathrm{O}$ peak in this core.

\section{THE BENTHIC FORAMINIFERAL $\delta^{18}$ O RECORDS}

The $\delta^{18} \mathrm{O}$ records of the benthic foraminifera from cores MD 73-025 and MD 84-527 are presented versus depth (Figure 1a and Figure 1d respectively), and versus interpolated ages (Figure 3). The signals are very similar in both cores. The glacial/ interglacial isotopic shift, 1.6 to $1.7 \%$ is of the same order of magnitude as that in the equatorial Pacific ocean core V 19-30 [Shackleton et al., 1983]. About $0.5 \%$ of this shift is attributed to a warming of the deep water at the location of the cores during deglaciation [Labeyrie et al., 1987]. However, detailed comparison of these records with other AMS-dated high sedimentation rate cores from the Pacific ocean [Shackleton et al., 1988, Kallel et al., 1988] indicates that the southern ocean benthic $\delta^{18} \mathrm{O}$ records do not represent accurately the heavy values of the last glacial maximum. In fact, the first of the classically described two steps corresponding to the initiation of the deglaciation (transition 1-A [Duplessy et al., 1981; Ruddiman and Duplessy, 1985]), is absent from our records. This event is dated in the equatorial Pacific ocean core TRI63-31 between 14.9 and 13.4 kyr B.P. (ages with no reservoir correction [Shackleton et al., 1988,]). Its absence may be explained by the mechanism advocated for planktonic foraminifera, i.e., downcore mixing from the levels of high benthic foraminiferal abundance during deglaciation (between 260 and $280 \mathrm{~cm}$ in core MD 84-527) to the low abundance levels of the last glacial maximum (between 300 and $340 \mathrm{~cm}$ [Ippolito, 1985]). The quality of the isotopic records is much better in the high sedimentation rate section of the core, from $290 \mathrm{~cm}$ upwards. As in the other high sedimentation rate cores, the trend of the second of the classically described two steps (termination 1B) is not linear but starts abruptly around $280 \mathrm{~cm}$ in both cores (Figures 1a and 1d), and becomes progressively more gentle upwards. The estimated age for the beginning of this transition is $12.6 \mathrm{kyr}$ B.P. for core MD 73-025 and 12.1 kyr B.P. for core MD 84527 . This age range is similar to the estimations realized in the North Atlantic Ocean [Duplessy et al., 1986; Bard et al., 1987] and in the Pacific Ocean [Kallel et al., 1988; Shackleton et al., 1988]. Holocene isotopic values are reached by $7 \mathrm{kyr}$ B.P.

\section{SEA SURFACE TEMPERATURE AND PLANKTONIC FORAMINIFERAL $\delta^{18}$ O RECORDS.}

The SST changes during deglaciation exceed $7^{\circ} \mathrm{C}$ for core $\mathrm{MD} 73-025$ (Figure 1c) and $5^{\circ} \mathrm{C}$ for core $\mathrm{MD} 84-527$ (Figure $1 \mathrm{~g})$, due to the southward migration of the polar front, from north of $40^{\circ} \mathrm{S}$ during the last glacial maximum [CLIMAP Project members, 1981] to its present location, between $42^{\circ}$ and $46^{\circ} \mathrm{S}$ in that area. The glacial values, below $4^{\circ} \mathrm{C}$, are not reliable for the foraminiferal T.F.

Core MD 73-025 (Figure 1b) presents a maximum glacial/ interglacial isotopic shift of $3 \%$ for the polar planktonic foraminiferal species $N$. pachyderma $s$. The total amplitude is only around $2 \%$ in core MD $84-527$. Yet the $3 \%$ figure is a minimum, if we take into consideration the possibility of downward flowing of foraminiferal shells from transition to glacial sediments. The detailed interpretation may begin in both cores MD 73-025 and MD 84-527 at $290 \mathrm{~cm}$, the depth 


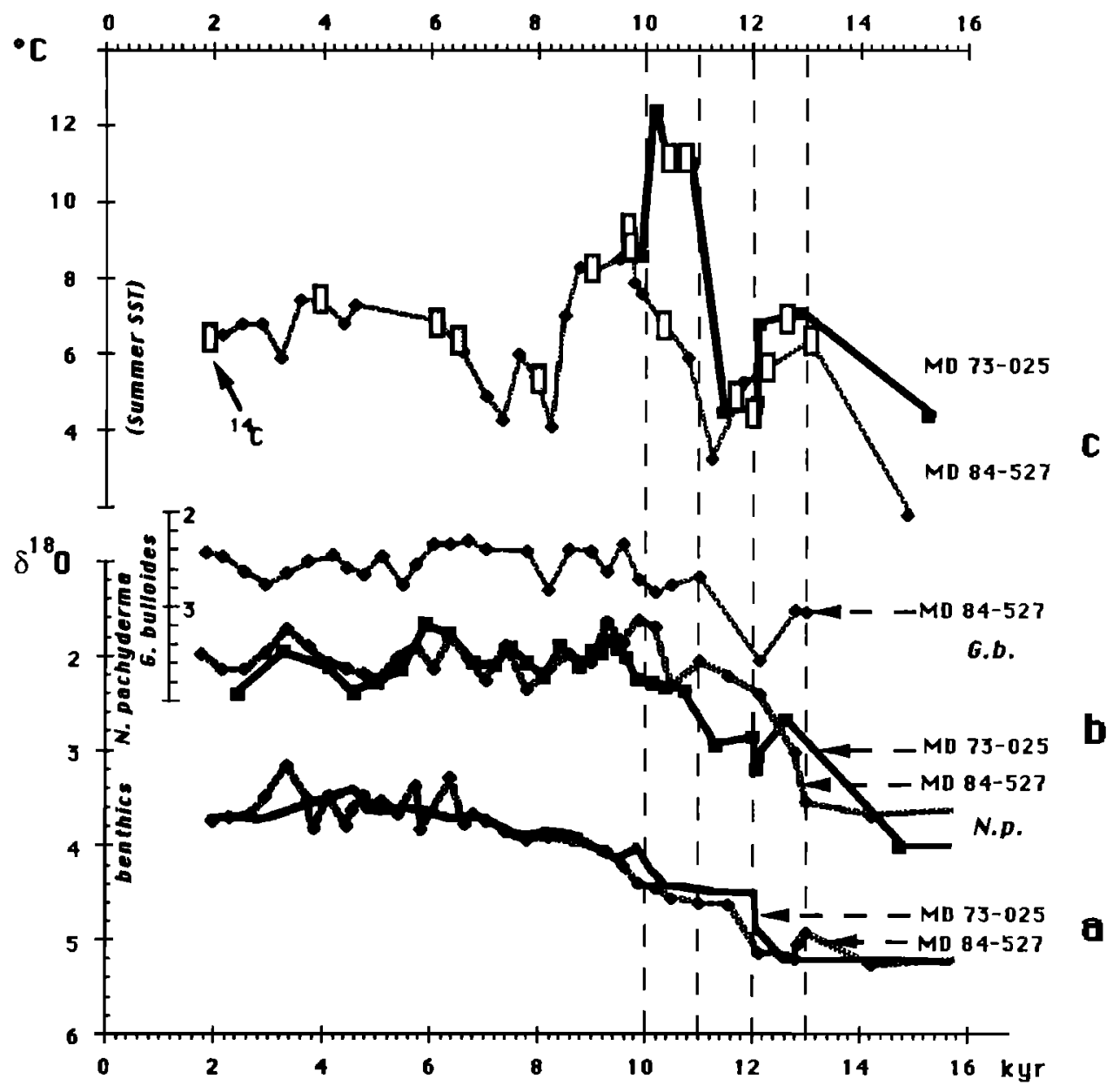

Fig. 3. Distribution versus calculated ages in cores MD 84-527 and MD 73-025, of (a) $\delta^{18} \mathrm{O}$ of the benthic foraminifera, (b) $\delta^{18} \mathrm{O}$ of the planktonic foraminifera (N.p.N. pachyderma s. ; G.b., G. bulloides), and (c) summer SST.

at which we observe a significant increase in the number of shells (Figure. 1h and li for core MD 84-527). This corresponds to $150-\mathrm{cm}$ depth in core MD 84-551.

Observation of core tops indicates that $N$. pachyderma $\delta^{18} \mathrm{O}$ are not far from isotopic equilibrium with water, considering a depth habitat of 50-100 m [Kellogg et al., 1978; Labeyrie and Duplessy, 1985], and spring hydrological conditions [Labeyrie et al., 1986]. The question is still open for $G$. bulloides, although unpublished results from our group indicate that in the north Atlantic the Holocene $\delta^{18} \mathrm{O}$ values are close to equilibrium if we follow the generally admitted concept that G. bulloides growth occurs during late spring and summer in surface temperate and subpolar waters, i.e., warmer waters than for $N$. pachyderma s.. The mean $\delta^{18} \mathrm{O}$ value of $G$. bulloides in core MD 84-527 is approximately $0.3 \%$ more positive that for $N$. pachyderma s.. There is a large isotopic gradient across the Antarctic polar front, with subtropical water heavier than polar waters by approximately $0.6 \%$ [Duplessy, 1970]. The simultaneous presence of both species in the core would be due to the seasonal and pluriannual oscillations of the polar front above the core location. Yet this effect appears insufficient to explain the heavy isotopic values of $G$. bulloides, if this species lives effectively in warmer waters than $N$. pachyderma. However, W. Howard and W. Prell (personal communication 1988) have found by statistical analysis of core tops on a global basis that $G$. bulloides is associated with colder waters in the southem ocean than in the north Atlantic, an added argument to explain the relatively high $\delta^{18} \mathrm{O}$ values of $G$. bulloides

The reliable record starts around $12.2 \mathrm{kyr}$ B.P. for core MD 84-551 (140 cm), $12.6 \mathrm{kyr}$ B.P. for core MD 73$025(280 \mathrm{~cm})$, and $13 \mathrm{kyr}$ B.P. for core MD $84527(290$ $\mathrm{cm}$ ), where the planktonic foraminiferal $\delta^{18} \mathrm{O}$ and the SST transfer function indicate a warm event with temperatures equivalent to the modern conditions. This warm event was immediately followed by a cold episode, indicated in the foraminiferal $\delta^{18} \mathrm{O}$ of the different cores studied and the SST estimates. Detailed comparison of the ${ }^{14} \mathrm{C}$ dates indicates, for the initial part of that episode, a transitory doubling of the mean sedimentation rate in core MD 73-025. This explains the 
TABLE 5. Age-Depth Relationship Between Cores MD 84-527 and MD 73-025

\begin{tabular}{ccc}
\hline $\begin{array}{c}\text { MD 84-527, } \\
\mathrm{cm}\end{array}$ & $\begin{array}{c}\text { MD 73-025, } \\
\mathrm{cm}\end{array}$ & age kyr \\
\hline 17 & 0 & 01.75 \\
60 & 0 & 02.40 \\
150 & 20 & 04.10 \\
201 & 85 & 07.00 \\
225 & 150 & 09.00 \\
251 & 195 & 09.70 \\
255 & 225 & 10.49 \\
271 & 230 & 10.70 \\
275 & 245 & 11.60 \\
280 & 250 & 12.00 \\
283 & 278 & 12.10 \\
300 & 280 & 12.60 \\
320 & 283 & 13.00 \\
345 & 332 & 25.00 \\
380 & 335 & 27.00 \\
400 & 340 & 28.30 \\
440 & 360 & 28.80 \\
500 & 365 & 30.80 \\
620 & 385 & 37.50 \\
710 & 530 & 42.00 \\
& 680 & 48.00 \\
\hline
\end{tabular}

better recording of its coldest phase, between $12 \mathrm{kyr}$ B.P. and $11 \mathrm{kyr}$ B.P. (Figure 3). A plateau, with intermediate isotopic values and temperatures similar to or higher than those for the modern ocean followed the cold phase, between $\sim 10.5 \mathrm{kyr}$ B.P. and $\sim 10 \mathrm{kyr}$ B.P., before reaching the lightest $\delta^{18} \mathrm{O}$ values. The period with maximum of temperatures is dated between 10.3 kyr B.P. and 8.9 kyr B.P. in core MD 84-527. The SST record of core MD 73-025 would start this warm event around 11 kyr B.P.

\section{IMPLICATIONS AND COMPARISON WITH OTHER RECORDS OF THE DEGLACIATION}

Our data set indicates therefore that at least in the Indian sector of the southern ocean, the postglacial warming was well established at 12.5 to $13 \mathrm{kyr}$ B.P. (Figure 3). These dates are not significantly different from the ages obtained in the northern hemisphere for the first large postglacial warming. They are concomitant with the decrease in Earth-Sun distance (increase in insolation) during summer over the high northern latitudes, i.e., during winter over the low southern latitudes (Bölling, dated between 13 and 12 kyr B.P. in northern Europe [Mangerüd et al., 1979]). However, in the high southern latitudes, this warm event was followed by a well-defined cold oscillation, which peaked around 12 to $11.5 \mathrm{kyr}$ B.P. and lasted to approximately $10.5 \mathrm{kyr}$ B.P. This period is therefore roughly synchronous with the succession of the Older Dryas, Alleröd, and Younger Dryas, continental chronozones described in Europe [Mangerüd et al., 1979]. However, the southern ocean records does not give any indication of the warm period characteristic of the Alleröd between 12 and 11 kyr B.P. As this age is supported both by the polar species $N$. pachyderma $s$. and by the subpolar species $G$. bulloides, which develop in well ventilated temperate waters, there is no reason to hypothesize a significant underestimation of the correction to apply to the surface water ages.

There are no precisely dated continental records within the same polar to subpolar climatic zone in the southern hemisphere, which could help to generalize our conclusions. The exceptional pollen record of Alerce (Chile), located at $41^{\circ} \mathrm{S}$, is influenced by the subtropical Pacific waters. Heusser and Streeter [1980] indicated in this record a first postglacial warm event peaking at 11,300 years B.P. $( \pm 900)$, followed by a pronounced cold period, before a second warm event (to temperatures higher than today's) dated between 9400 and 8600 years B.P. Their cold oscillation is therefore apparently synchronous with the northern hemisphere Younger Dryas. However, more recently, Heusser and Rabassa [1987] and Heusser [1989] evidenced a transitory cooling marked by a drop of pollen influx between $11,850( \pm 50)$ and 10,500 years B.P. $( \pm 80)$ in the southernmost South America. There is here a clearer correspondence with the dating of the cold event in the southern ocean records. Our results indicate therefore that the rapid succession of climatic oscillations described by the European palynologists, which culminated during the Younger Dryas, was different in the high southern latitudes. The early part of the cold oscillation, around $12 \mathrm{kyr}$ B.P., appears synchronous with the cold Older Dryas in Europe, but it was not followed by a warming similar to the mild Bolling-Allerôd interstadial. The warming started only after $11 \mathrm{kyr}$ B.P., apparently synchronous to the Younger Dryas cold in western Europe and northeast of America. This could highlight the Bolling-Allerobd period as anormally warm, if we take into consideration the amount of continental ice still present in the Fenno-Scandinavian and the Laurentide ice sheets.

The climatic optimum, around $10 \mathrm{kyr}$ B.P. in the southern ocean (well defined also in Alerce), is better marked but in phase with the warming to Holocene temperatures observed in the northeast Atlantic Ocean [Duplessy et al., 1987].

The difference in the timing of the deglaciation appears therefore limited to the 12- to 10-kyr B.P. period, with an apparent 1-kyr lag of the northern hemisphere cold Younger Dryas compared to the southern ocean SST record. Such time constant indicates that continental ice, deep water circulation, and their consequences on atmospheric $p \mathrm{CO}_{2}$, may be involved in this oscillatory behavior of the global climate system during the deglaciation. A quantitative reconstruction of the changes of climate at that period will have to wait for reliable climate models including interactive ocean, atmosphere, and ice. Yet taking into account the differences in the timings and local responses, other time series are necessary, especially in the poorly known southem hemisphere.

Acknowledgments. We thank J. Antignac, E. Kaltnecker, H. Leclaire, B. Le Coat, and P. Maurice for help in the analyses; A. Castera, D. de Zertucha, and J. Dudouit for their help in developing AMS, and C. Lalou for the finalisation of the manuscript. M. Fontugne and J.-L. Turon plaid a major role in the different APSARA coring cruises, we thank them as well as the captains and crews of the M.S. Marion Dufresne. W. Prell made available for us the data base of the foraminiferal F1.2 T.F., and various softwares developped within the CLIMAP and SPECMAP NSF programs. This work was supported by Centre National de la Recherche Scientifique, Institut National des Sciences de 1'Univers, 
Programme National d'Etude de la Dynamique du Climat, Commissariat à l'Energie Atomique, Mission Scientifique des Terres Australes et Antarctiques Françaises, and EEC grant EV4C-0072-F. CFR contribution 1037.

\section{REFERENCES}

Bard, E., M. Arnold, P. Maurice, J. Duprat, J. Moyes, and J.C. Duplessy, Retreat velocity of the North Atlantic polar front during the last deglaciation determined by ${ }^{14} \mathrm{C}$ accelerator mass spectrometry, Nature, 328, 791-794, 1987.

Bard, E., L. Labeyrie, M. Amold, M. Labracherie, J.-J. Pichon, J. Duprat, and J.-C. Duplessy, AMS $-{ }^{14} \mathrm{C}$ ages measured in deep sea cores from southern ocean: Implications for sedimentation rates during isotopes stage 2, Quat. Res., 31, 309-317, 1989.

Broecker, W. S., M. Andrée, W. Wolfli, H. Oeschger, G. Bonani, J. Kennett, and D. Peteet, The chronology of the last deglaciation: Implications to the cause of the Younger Dryas event, Paleoceanography , 3, 1-19, 1988.

CLIMAP Project Members, Seasonal reconstructions of the Earth's surface at the last glacial maximum, Geol. Soc. Am. Map and Chart Series 36, 1981.

Duplessy, J.-C., Note préliminaire sur les variations de la composition isotopique des eaux superficielles de l'Océan Indien: La relation O18-salinité, C. R. Acad. Sci. Paris, 271, 1075-1078, 1970.

Duplessy, J.-C., G. Delibrias, J.-L. Turon, C. Pujol, and J. Duprat, Deglacial warming of the northeastern Atlantic ocean: Correlation with the paleoclimatic evolution of the European continent, Palaeogeogr. Palaeoclimatol. Palaeoecol., 35, 121-144,1981.

Duplessy, J.-C., M. Arnold, P. Maurice, E. Bard, J. Duprat, and J. Moyes, Direct dating of the oxygen-isotope record of the last deglaciation by ${ }^{14} \mathrm{C}$ accelerator mass spectrometry, Nature, 320, 350-352, 1986.

Duplessy, J.-C., E. Bard, M. Arnold, and P. Maurice, AMS ${ }^{14} \mathrm{C}$ chronology of the deglacial warming of the north Atlantic Ocean, Nucl. Instrum. Methods, B29, 223-227, 1987.

Duplessy, J.-C., M. Amold, E. Bard, A. Juillet-Leclerc, N. Kallel, and L. Labeyrie, AMS C-14 study of transient events and of the ventilation rate of the Pacific intermediate water during the last deglaciation, Radiocarbon, in press, 1989.

Gordon, A. L., and E. J. Molinelli, Thermohaline and chemical distributions and the atlas data set, in Southern Ocean Atlas, pp. 1-11, A. A. Balkema, Rotterdam, 1986.

Hays, J. D., A review of the Late Quaternary climatic history of Antarctic Seas, in Antarctic glacial history and world palaeoenvironments, Proceedings of the Xth INQUA Congress, edited by E. M. van Zinderen Bakker, pp. 5771, A. A. Balkema, Rotterdam, 1978.

Heusser, C. J., Late Quaternary vegetation and climate of southern Tierra del Fuego, Quat. Res., 31, 396-406, 1989.

Heusser, C. J., and J. Rabassa, Cold climatic episode of Younger Dryas age in Tierra del Fuego, Nature, 328, 609611, 1987.
Heusser, C. J., and S. S. Streeter, A temperature and precipitation record of the past 16,000 years in southern Chile, Science, 210, 1345-1347, 1980.

Hutson, R., and W. Prell, A paleoecological transfer function F 1-2, for Indian Ocean planktonic foraminifera, $J$. Paleontol. ,54 (2), 381-399, 1980.

Imbrie, J., and N. G. Kipp, A new micropaleontological method for quantitative paleoclimatology: application to a late pleistocene Caribbean core. in The Late Cenozoic Glacial Ages, edited by K. K. Turekian, pp.71-181, Yale University Press, New Haven, Conn., 1971.

Ippolito P., Contribution de l'analyse de la microfaune planctonique et benthique à la paleo-oceanographie de l'Ocean Austral, Ph.D. thesis $n^{\circ} 2103$, Univ. of Bordeaux 1, Talence, France, 1985.

Kallel, N., L. D. Labeyrie, M. Arnold, H. Okada, W. C. Dudley, and J.-C. Duplessy, Evidence of cooling during the Younger Dryas in the western North Pacific, Oceanol. Acta, 11, 369-376, 1988.

Kellogg, T. B., N. J. Shackleton, and J.-C. Duplessy, Planktonic foraminiferal and oxygen isotopic stratigraphy and paleoclimatology of Norwegian Sea deep sea cores, Boreas, 7, 61-73, 1978.

Labeyrie, L. D., and J.-C. Duplessy, Changes in the oceanic ${ }^{13} \mathrm{C} /{ }^{12} \mathrm{C}$ ratio during the last 140,000 years: High latitude surface water records, Palaeogeogr., Palaeoclimatol., Palaeoecol., 50, 217-240, 1985.

Labeyrie, L. D., J.-J. Pichon, M. Labracherie, P. Ippolito, J. Duprat, and J.-C. Duplessy, Melting history of Antarctica during the past 60,000 years, Nature, 322, 701-706, 1986.

Labeyrie, L. D., J.-C. Duplessy, and P.-L. Blanc, Variations in mode of formation and temperature of oceanic deep waters over the past 125,000 years, Nature, $327,477-482$, 1987.

Mangerüd, J., E. Larsen, O. Longva, and E. Sontegaard, Glacial history of westem Norway $15,000-10,000$ B.P., Boreas, 8, 179-187, 1979.

Morley, J. J., and W. Robinson, Paleotemperature and faunal variations in two deep sea records from the Northern Cape Basin, Geol. Soc. Am. Abst. Programs, 12, 487, 1980

Ruddiman, W. F., and J.-C. Duplessy, Conference on the last deglaciation: Timing and mechanism, Quat. Res., 23 (1), 1-17, 1985 .

Shackleton N. J., J. C. Duplessy, M. Amold, P. Maurice, M. A. Hall, and J. Cartlidge, Radiocarbon age of last glacial Pacific deep water, Nature, 335, 708-711, 1988.

M. Arnold, E. Bard, J.-C. Duplessy, and L. D. Labeyrie, Centre des Faibles Radioactivités, Laboratoire mixte CNRSCEA, Avenue de la Terrasse, 91198 Gif-sur-Yvette Cedex, France.

J. Duprat, M. Labracherie, and J.-J. Pichon, Département de Géologie et Océanographie, U.A. 197, Université de Bordeaux 1, Avenue des Facultés, 33405 Talence Cedex, France.

(Received March 28, 1989; revised July 27, 1989 . accepted August 1, 1989.) 